Cord 2009, 25 (2)

\title{
Sugar Cane Cake and Mineral Fertilizers on Coconut (Cocos nucifera Linn.) Seedlings
}

\author{
Luiz Gonzaga Bione Ferraz ${ }^{1}$, Ademar Barros da Silva², José Nunes Filho ${ }^{1}$, \\ Antonio Raimundo de Sousa ${ }^{1}$ and Venézio Felipe dos Santos ${ }^{1}$
}

\begin{abstract}
High quantities of mineral fertilizers (MF) are required for good coconut seedling production, whose up dated recommendation is 232 grams per seedling. The objective of this work was to assess the substitution of the MF by organic fertilizer as sugar-cane filter cake (SCFC) on coconut seedlings in polybag. The SCFC is an organic residue from sugar-cane manufacturing composed of various chemical elements, as for instance: nitrogen, phosphorus, potassium, calcium and magnesium. The experiment was carried out at the Itapirema Research Station, Goiana, Pernambuco State, Brazil, in a randomized complete block design, with factorial disposition $5^{2}$, replicated three times, with six tall coconut seedlings per plot. The treatments were the combinations of five doses of MF (in g seedling $^{-1}$ ): 46.25; $92.50 ; 138.75 ; 185.00$ and control, using urea, simple superphosphate and potassium chloride at the proportion of 1:2:3, respectively, and five doses of SCFC (in kg polybag ${ }^{-1}$ ): $0.5 ; 1.0 ; 1.5 ; 2.0$ and control. Eight months after young coconut seedlings replacement to the polybags the following parameters were measured: collar girth (CG), leaf area (LA), number of live leaves (NL) and plant height (PH). For leaf nutritional diagnosis and growing media chemical and physical analyses, samples were collected. There was significance for the two factors, individually, to all parameters. The trend analysis revealed linear, quadratic and cubic responses, according to the studied character. The mixture of $0.5 \mathrm{~kg}$ of SCFC polybag $^{-1}$ plus $46.25 \mathrm{~g}$ of the MF was sufficient for obtaining seedlings of excellent quality and promoting a fertilizers economy around $80 \%$. According to other results from this research, the number of seedlings per plot and the critical level of nutrients in the leaf of coconut seedlings should be reviewed.
\end{abstract}

Keywords: Organic matter; sugar mill by-product; nutrient economy; foliar diagnosis.

1 - Avenida General San Marin, 1371. Bonji. CEP 5550761-000. P.O. Box 1022, Recife - PE, Brazil. E-mail: bione@ipa.br./nunesfilho@ipa.br / ar@ipa.br / venezio@ipa.br.

2 - Rua Antonio Falcão, 402. Boa Viagem. CEP 5551020-240. Recife - PE, Brazil.

E-mail: ademar@uep.cnps.embrapa.br. 


\section{Introduction}

The use of organic residues for coconut seedlings production is a world-wide recommended practice. However its quantities are not always based on research results, but due to the organic matter to be known as an improver of soil conditions.

The coconut seedling production technique in polybags started in the Ivory Coast, in substitution of the dry land production technique (Wuidart, 1981). Some advantages and disadvantages of these two methods were presented before (Wuidart, 1981, Passos, 1983, Fontes and Leal, 1998 and Ohler, 1999).

Elevated quantities of chemical fertilizers are recommended for coconut seedling during nursery period. These quantities vary between 200 to 270 gram/ (Rognon, 1971, Wuidart, 1981, Embrapa, 1993,Ohler, 1999). Comparing with the quantities used in others fruit crops, it is a very expensive practice.

Others coconut seedling fertilization methods (Mathew and Ramadasan, 1964; Brunin et al. 1975; Santiago, 1978) were based basically on the determination of the quantity, the fraction and the source of the mineral fertilizers. In the other hand, it is known that the organic matter improves the soil structure and water-holding capacity, as described by Ohler (1999) but, no scientific information of the SCFC use and effect in the coconut seedlings production were found.

In Brazil, the coconut cultivation is concentrated in the Northeast region, sharing the agricultural area with the sugarcane crops. One of the industrial sugarcane processing residues is the filter cake (SCFC), which can be used as organic fertilizer for seedlings production in general.

In Brazilian Northeast, the sugarcane filter cake production was around $1,300,000$ ton per year (Siqueira, 1988). In Pernambuco State of Brazil, it is produced around 16, 000, 000 ton of sugarcane, corresponding to a 600,000 ton of SCFC per year $(40 \mathrm{~kg}$ of filter cake per ton of sugarcane).

The mean composition (in \%) of the SCFC is: $\mathrm{N}=1.50 ; \mathrm{P}_{2} \mathrm{O}_{5}=1.60 ; \mathrm{K}_{2} \mathrm{O}=0.70 ; \mathrm{Ca}^{2+}=$
5.52; $\mathrm{Mg}^{2+}=0.52$ and $\mathrm{S}=1.44$, which varies depending on the sugar-cane soup treatment in the sugar mill (Ematerpe, 1980). These results, indicate that the use of sugarcane-based organic fertilizer can be capable of reducing MF (mineral fertilizers) application and improve the low fertility soil physical conditions, found on extensive coconut plantation area.

So, the objective of this paper was to show that it is possible to replace partially the mineral fertilizers by sugarcane filter cake without interfering on the coconut seedling qualities and to promote an excellent fertilizers economy.

\section{Material and methods}

The experiment was carried out at the Itapirema Research Station $\left(07^{\circ} 33^{\prime} 45^{\prime}\right.$ ' S; $35^{\circ}$ 00'00” WG), in Goiana, Pernambuco State, Brazil. It is located in the coastal humid forest zone (annual rainfall mean around $1900 \mathrm{~mm}$, concentrated from March to September), $15 \mathrm{~m}$ above sea level and distant $25 \mathrm{~km}$ of the seacoast.

A randomized complete block (RCB) design on factorial disposition $5^{2}$, with three repetitions and six tall coconut seedlings per plot was utilized in this experiment. A Yellow Red Podzolic, dystrophic, sandy texture, from the upper layer, was used in the polybags (Brazil, 1969). The soil composition was: $\mathrm{P}=4$ $\mathrm{mg} \mathrm{kg}{ }^{-1}, \mathrm{~K}^{+}=0.03 \mathrm{cmol}_{\mathrm{c}} \mathrm{kg}^{-1}, \mathrm{Ca}^{2+}=\mathrm{Mg}^{2+}=1.1$ $\mathrm{cmol}_{\mathrm{c}} \mathrm{kg}^{-1}, \mathrm{Al}^{3+}=0.7 \mathrm{cmol}_{\mathrm{c}} \mathrm{kg}^{-1}, \mathrm{pH}=4.5$, organic matter $=11.20 \mathrm{~g} \mathrm{~kg}^{-1}$ and sand $=890 \mathrm{~g}$ $\mathrm{kg}^{-1}$. According to the newest Brazilian classification (Embrapa, 2006), this soil is known as Yellow Red Argissol.

The composition (in \%) of the used SCFC was the following: $\mathrm{N}=2.25 ; \mathrm{P}=2.21 ; \mathrm{K}^{+}=$ 0.35 and $\mathrm{Ca}^{2+}=\mathrm{Mg}^{2+}=3.96$. The SCFC was maintained under air exposition from March to December to, reducing its moisture content from $75.00 \%$ to $18.66 \%$.

The SCFC and soil were screened on 4 $\mathrm{mm}$ and mixed to get the following rates of the SCFC in $\mathrm{kg} /$ seedling or per polybag: $0.5 ; 1.0$; $1.5 ; 2.0$ and control. The final quantities of the 
SCFC in the soil substrate were (in \%): 2.38; $4.78 ; 7.16 ; 9.55$ and 0.00 , respectively. To obtain these doses and percentages, the SCFC and soil mixture presented the follow volumetric proportions: $1: 25 ; 1: 12.50 ; 1: 8.33 ; 1: 6.50$ and $0: 25$; respectively.

The young coconut seedlings selection in seedbed was done when they were about $15 \mathrm{~cm}$ high. At this time, roots were cut near the nut (2 $\mathrm{cm}$ ) and they placed into bag (black polyethylene, $45 \mathrm{~cm} \times 45 \mathrm{~cm} \times 0.20 \mathrm{~mm}$, with holes for drainage) with $2 / 3$ of the media growth or substrate (mixture of SCFC and soil). After replacement the polybags were positioned in equilateral triangle with $0.90 \mathrm{~m}$ side. Water need during nursery stage $\left(200 \mathrm{~mm} \mathrm{month}{ }^{-1}\right)$ was supplied by sprinkling irrigation.

The applied MF was based on Embrapa (1986), as follows: a) urea; simple superphosphate and potassium chloride proportion $=1: 2: 3$, respectively; and $b$ ) the MF's mixture quantity per seedling refers to the total rate/seedling $(\mathrm{g})=46.25 ; 92.50 ; 138.75 ; 185.00$ and control. After the young seedlings have been placed into the polybags, the MF's doses were applied monthly, from the first to the fifth month. Thus, monthly application of MF mixture (in $\mathrm{g}$ seedling ${ }^{-1}$ ) was: $9.25 ; 18.50 ; 27.75 ; 37.00$ and control, respectively. So, the 25 treatments represented the five doses of SCFC combination (in $\mathrm{kg} \mathrm{polybag}^{-1}$ ) with the five doses of MF (in $\mathrm{g}$ seedling $\left.{ }^{-1}\right)$.

Eight months old seedlings were measured for: collar girth (CG), leaf area (LA), number of live leaves (NL) and plant height (PH). For leaf nutritional diagnosis, samples from the leaf rank 1 were collected. In this same period, soil samples (growing media) for chemical and physical analyses were also collected.

Leaf area was determined with the equation: LA $=0.0878$. L.W (Krishna Marar and Pappachan, 1964). It defines the area of each leaf, where $\mathrm{L}=$ length of opened leaf (from base to top of straightened leaf); $\mathrm{W}=$ width of unopened leaf (measured on its widest part). The PH was measured from girth to the top of the youngest leaf at the vertical position.

\section{Results and discussion}

In general, there was significance difference in analysed parameters between sugar cane filter cake (SCFC) and mineral fertilizer (MF) (Table 1). There was significance difference in the results from the biggest rates of the SCFC with those from the smallest rates of the MF and vice-versa.

For collar girth (CG) and leaf area (LA) the smallest dose of MF presented a better result than the biggest one of SCFC. On the other hand, the maximum dose of SCFC performed better than the maximum dose of MF for leaves (NL) and plant height (PH) (Table 1).

The trend analysis presented linear, quadratic and cubic responses according to the factor and studied parameter.

\section{Collar girth (CG)}

Both SCFC (Figure 1) and MF (Figure 2) presented significant quadratic response to collar girth (CG), indicating an association between them.

The biggest mean obtained for CG was $20.94 \mathrm{~cm}$ (Table 1) from the treatment with the maximum doses of SCFC and MF. However the combination of their smallest doses $(0.5 \mathrm{~kg}$ and $46.25 \mathrm{~g}$ ) was enough to get the CG measuring $18.11 \mathrm{~cm}$, placing it at the same statistic group of the above cited CG. And increasing SCFC dose to $1.5 \mathrm{~kg}$, maintaining $\mathrm{MF}$ at $46.25 \mathrm{~g}$, it was sufficient for elevating the CG to $19.50 \mathrm{~cm}$. 
Table 1. Collar girth (CG), leaf area (LA), number of live leave (NL) and plant height (PH) for eight months old coconut seedlings, in relation to the sugar-cane filter cake (SCFC) and mineral fertilizers (MF), with $F$ value and variation coefficient (VC)

\begin{tabular}{|c|c|c|c|c|c|}
\hline \multicolumn{2}{|c|}{ Treatment } & \multicolumn{4}{|c|}{ Parameter } \\
\hline $\begin{array}{c}\mathrm{SCFC} \\
\left(\mathrm{kg} \mathrm{bag}^{-1}\right)\end{array}$ & $\begin{array}{c}\text { MF } \\
\left(\text { g seedling }^{-1}\right)\end{array}$ & $\mathrm{CG}(\mathrm{cm})$ & $\mathrm{LA}\left(\mathrm{cm}^{2}\right)$ & NL & $\mathrm{PH}(\mathrm{cm})$ \\
\hline 2.0 & 185.00 & $20.94 \mathrm{a}$ & $913.72 \mathrm{a}$ & $7.33 \mathrm{abc}$ & $118.83 \mathrm{a}$ \\
\hline 2.0 & 138.75 & $20.46 \mathrm{ab}$ & $862.55 \mathrm{abcd}$ & $7.54 \mathrm{a}$ & $113.08 \mathrm{abcd}$ \\
\hline 0,5 & 185.00 & $20.01 \mathrm{abc}$ & 849.04 abcd & $7.20 \mathrm{abcd}$ & $115.19 \mathrm{abc}$ \\
\hline 1.5 & 138.75 & $20.00 \mathrm{abc}$ & 882.44 abcd & $7.11 \mathrm{abcd}$ & $115.63 \mathrm{abc}$ \\
\hline 1.0 & 92.50 & $19.83 \mathrm{abc}$ & 815.00 abcde & 7.00 abcde & $112.50 \mathrm{abcd}$ \\
\hline 1.0 & 138.75 & $19.77 \mathrm{abc}$ & $899.44 \mathrm{ab}$ & 7.00 abcde & $116.66 \mathrm{ab}$ \\
\hline 1.5 & 185.00 & $19.66 \mathrm{abc}$ & $863.55 \mathrm{abcd}$ & $7.33 \mathrm{abc}$ & $118.00 \mathrm{a}$ \\
\hline 1.0 & 185.00 & $19.55 \mathrm{abcd}$ & 813.27 abcde & 6.94 abcde & $112.77 \mathrm{abcd}$ \\
\hline 1.5 & 46.25 & $19.50 \mathrm{abcd}$ & $893.94 \mathrm{abc}$ & $7.39 \mathrm{ab}$ & $117.16 \mathrm{a}$ \\
\hline 1.5 & 92.50 & $19.22 \mathrm{abcd}$ & 772.05 abcde & 6.83 abcdef & $111.44 \mathrm{abcd}$ \\
\hline 2.0 & 92.50 & $19.05 \mathrm{abcd}$ & $859.22 \mathrm{abcd}$ & $7.33 \mathrm{abc}$ & $114.33 \mathrm{abc}$ \\
\hline 1.0 & 46.25 & $18.94 \mathrm{abcd}$ & 777.77 abcde & $7.16 \mathrm{abcd}$ & $107.66 \mathrm{abcd}$ \\
\hline 0.5 & 138.75 & $18.83 \mathrm{abcd}$ & 820.38 abcde & $7.11 \mathrm{abcd}$ & $116.83 \mathrm{a}$ \\
\hline 2.0 & 46.25 & 18.61 abcde & 817.66 abcde & 6.89 abcde & $113.44 \mathrm{abc}$ \\
\hline 0.0 & 185.00 & 18.55 abcde & 780.66 abcde & $6.66 \mathrm{bcdefg}$ & $111.55 \mathrm{abcd}$ \\
\hline 0.5 & 92.50 & 18.35 abcdef & 794.23 abcde & 7.02 abcde & $108.67 \mathrm{abcd}$ \\
\hline 0.0 & 138.75 & 18.35 abcdef & 745.94 abcde & 6.94 abcde & $107.62 \mathrm{abcd}$ \\
\hline 0.5 & 46.25 & $18.11 \mathrm{abcdef}$ & 743.72 abcde & $7.05 \mathrm{abcd}$ & $104.55 \mathrm{abcd}$ \\
\hline 0.0 & 92.50 & 17.90 bcdef & $675.08 \mathrm{ef}$ & 6.51 cdefg & $102.46 \mathrm{bcd}$ \\
\hline 0.0 & 46.25 & 17.58 cdef & 723.34 cde & $6.56 \mathrm{bcdefg}$ & $105.53 \mathrm{abcd}$ \\
\hline 2.0 & 00.00 & 16.85 defg & $717.22 \mathrm{def}$ & 6.76 abcdef & $106.60 \mathrm{abcd}$ \\
\hline 1.0 & 00.00 & 16.66 & $659.94 \mathrm{ef}$ & $6.38 \mathrm{defg}$ & 102.44 bcde \\
\hline 1.5 & 00.00 & 15.89 & $653.11 \mathrm{efg}$ & $6.17 \mathrm{efg}$ & $101.22 \mathrm{cde}$ \\
\hline 0.5 & 00.00 & 15.50 & $547.38 \mathrm{fgh}$ & $6.00 \mathrm{fg}$ & $92.95 \mathrm{de}$ \\
\hline 0.0 & 00.00 & 14.50 & $762.77 \mathrm{~h}$ & $5.83 \mathrm{~g}$ & $88.61 \mathrm{e}$ \\
\hline F value to $S$ & & $9.9123 * *$ & $19.5867 * *$ & $11.8165^{* *}$ & $12.4729 * *$ \\
\hline $\mathrm{F}$ value to $\mathrm{M}$ & & $43.3403 *$ & $47.8709 * *$ & $27.1860 * *$ & $32.0182 * *$ \\
\hline F value to $S$ & $\times \mathrm{MF}$ & $0.7735^{\text {n.s }}$ & $1.7307^{*}$ & $1.5631^{\mathrm{ns}}$ & $1.6294^{\mathrm{ns}}$ \\
\hline V.C (\%) & & 4.90 & 7.00 & 4.01 & 4.73 \\
\hline
\end{tabular}

Means followed by distinct letters differ among themselves (Tukey, 5\%). 
Figure 1. Coconut seedling collar girth $(\mathrm{cm})$ in function of the sugar-cane filter cake

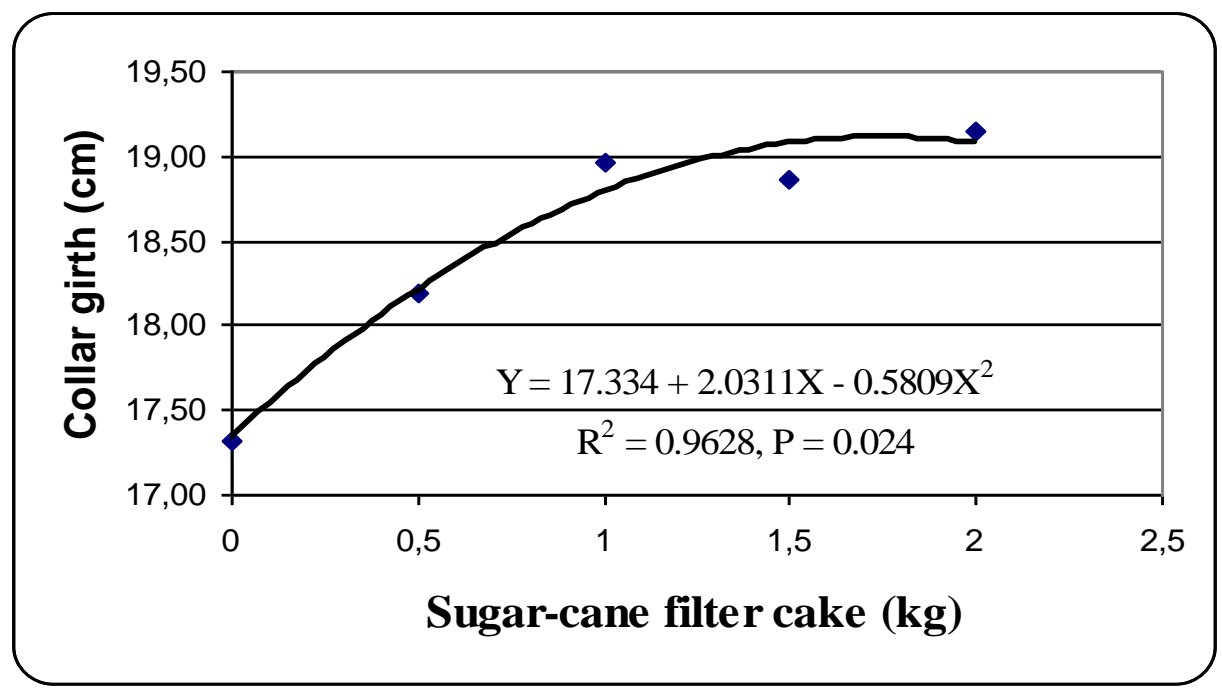

Figure 2. Coconut seedling collar girth $(\mathrm{cm})$ in function of mineral fertilizer

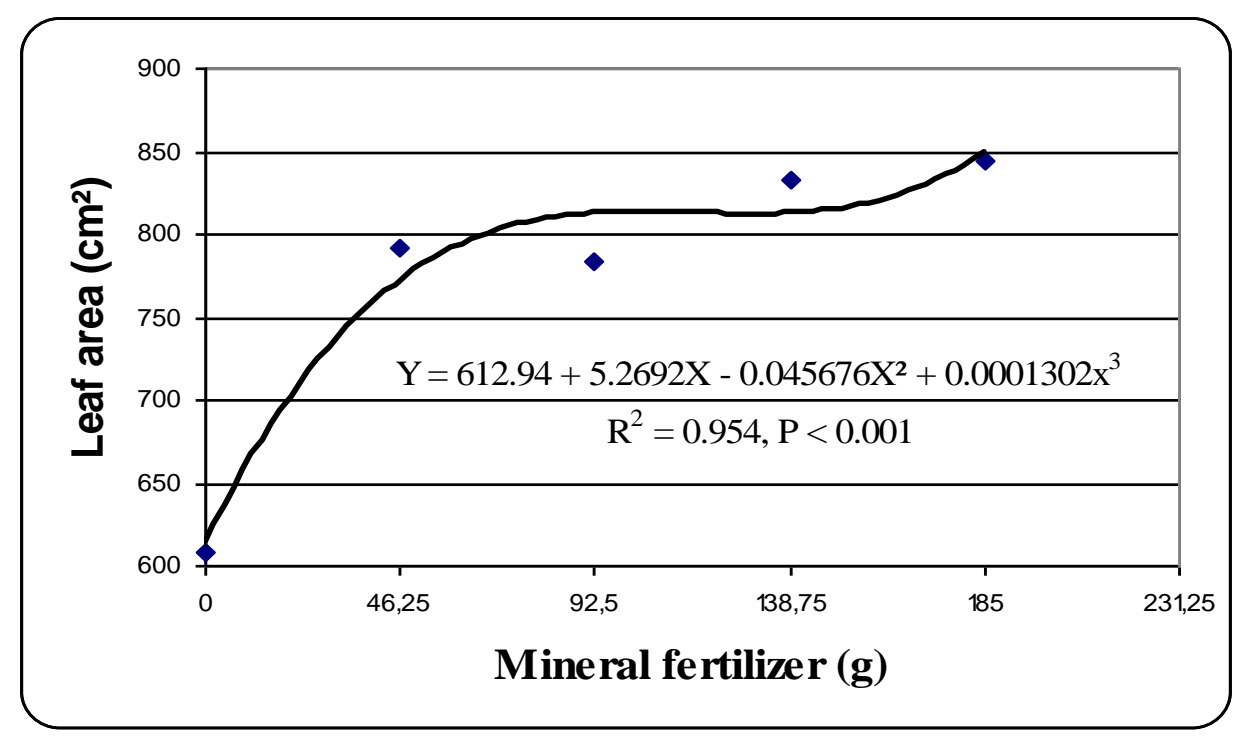

Leaf area (LA) 
The SCFC performance for LA was similar to $\mathrm{CG}$, presenting a quadratic response (Figure 3). This performance differ from the MF, which presented a cubic response (Figure 4).

The minimum applied doses of SCFC (0.5 $\mathrm{kg}$ ) and MF (46.25 g) were enough to obtain a LA equal to $743.72 \mathrm{~cm}^{2}$ (Table 1), positioning it at the same statistic group of the biggest doses $\left(913.72 \mathrm{~cm}^{2}\right)$ tested. However, the combination of $1.5 \mathrm{~kg}$ SCFC and the same $46.25 \mathrm{~g} \mathrm{MF}$ increased LA to $893.94 \mathrm{~cm}^{2}$ (Table 1).

\section{Number of alive leaves (NL)}

The trend analysis for the two factors presented inverse response when compared to the LA. The SCFC presented a cubic response (Figure 5) and the MF a quadratic one (Figure 6).

In this case, the SCFC performed still better than the CG and LA. The treatment with $0.5 \mathrm{~kg} \mathrm{SCFC}$ and $46.25 \mathrm{~g} \mathrm{MF}$ obtained NL equal to 7,05, at the same statistical group and nearer of the best one (7,33), while $1.5 \mathrm{~kg}$ SCFC and 46.25 g MF had a better result, obtaining 7,39 (Table $1)$.

\section{Plant Height (PH)}

The $\mathrm{PH}$ presented a linear regression response (Figure 7) to the SCFC and a quadratic response to the MF (Figure 8). There was no significance difference between the biggest doses of both treatment factors $(118,83 \mathrm{~cm}$ with $2,0 \mathrm{~kg}$ $+185 \mathrm{~g})$ and the smallest ones $(104,55 \mathrm{~cm}$ with $0.5 \mathrm{~kg}+46.25 \mathrm{~g}$ ) (Table 1). Increasing the SCFC to $1.5 \mathrm{~kg}$ and remaining the MF equal to $46.25 \mathrm{~g}$, was sufficient to getting the PH equal to 117.16 $\mathrm{cm}$ (Table 1).

\section{Foliar Diagnosis - Critical Level}

The contents of the chemical elements such as $\mathrm{N}, \mathrm{P}, \mathrm{K}^{+}, \mathrm{Ca}^{2+}, \mathrm{Mg}^{2+}$ and $\mathrm{Na}^{+}$in leaf of rank 1 are presented in the Table 2. For N, the absolute control presented the highest content $(1.40 \%)$. After that, came all treatments with SCFC without MF. Different doses of MF did not interact with the $\mathrm{N}$ content in leaf. The

Figure 3. Coconut seedling leaf area $\left(\mathrm{cm}^{2}\right)$ in function of the sugar-cane filter cake

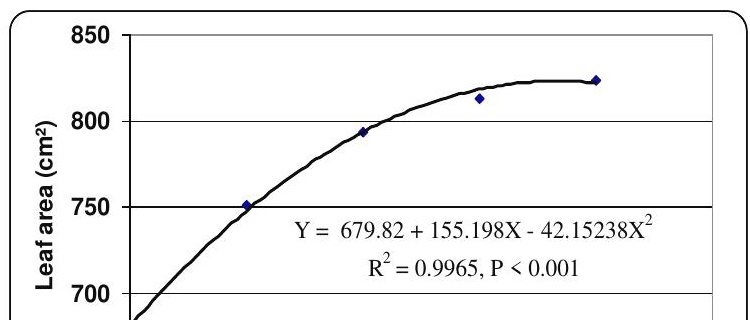

combination of the biggest doses of the two studied factors presented the smallest $\mathrm{N}$ leaf contents.

It was also observed that the SCFC and MF were important for $\mathrm{P}$ contents increasing in leaf. The SCFC have shown to be more representative for $\mathrm{P}$ increasing than the $\mathrm{MF}$ and their combination. It is possible to correlate the high contents of $\mathrm{P}$ with the SCFC.

The results from SCFC applications were negatives for $\mathrm{K}^{+}$content. In fact, the $\mathrm{K}^{+}$content decreases as increasing SCFC doses. However, MF increased $\mathrm{K}^{+}$contents without a direct relation to the applied doses.

The biggest contents of $\mathrm{Ca}^{2+}$ and $\mathrm{Mg}^{2+}$ were found in SCFC applications with or without MF. The MF treatments promoted a $\mathrm{Ca}^{2+}$ and $\mathrm{Mg}^{2+}$ contents reduction. This result is possible be related to the SCFC high contents of $\mathrm{Ca}^{2+}$ and $\mathrm{Mg}^{2+}$.

For $\mathrm{Na}^{+}$, the contents increased with the SCFC and decreased with the MF applications. Probably due to the competitive absorption between $\mathrm{Na}^{+}$and $\mathrm{K}^{+}$, that always has $\mathrm{K}^{+}$ elevated content when the $\mathrm{MF}$ had being applied.

Even with the satisfactory results from this study, it was not possible to reach the nutrient critical levels for $\mathrm{N}, \mathrm{K}^{+}, \mathrm{Mg}^{2+}$ and $\mathrm{Ca}^{2+}$ in the leaves of coconut seedlings, whose maximum values were $1.40 \%, 2.46 \%, 0.21 \%$ and $0.36 \%$, respectively (Table 2 ).

The critical level contents are in disagree with Manciot et al. (1980), to $\mathrm{N}, \mathrm{K}^{+}$and $\mathrm{Mg}^{2+}$ $(1.7 \%, 3.0 \%$ and $0.27 \%$, respectively), and with Magat (1975), cited by Santiago (1978), to $\mathrm{Ca}^{2+}$, considering the leaf ranking 14 equal to $0.5 \%$. Phosphorus $(0.16 \%)$ was the unique element whose treatments, except the absolute control, got the critical level.

It was not surprising to get excellent vegetative results and elements contents in

Figure 4. Coconut seedling leaf area $\left(\mathrm{cm}^{2}\right)$ in function of mineral fertilizer

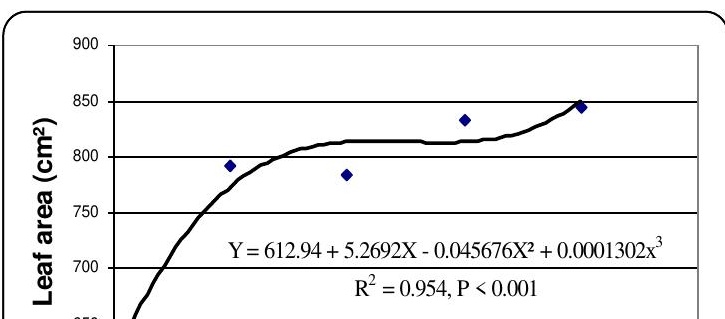


Figure 5. Number of live leaves on coconut seedling in function of the sugarcane filter cake

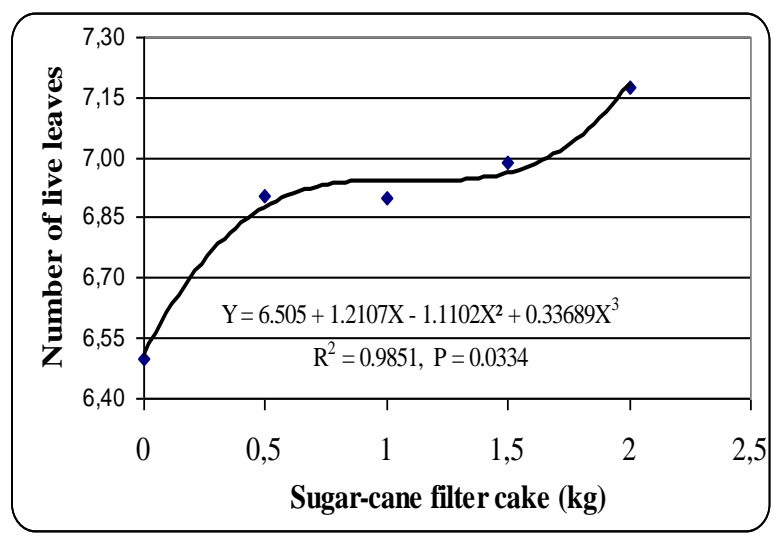

Figure 7. Coconut seedling height $(\mathrm{cm})$ in function of sugar-cane filter cake

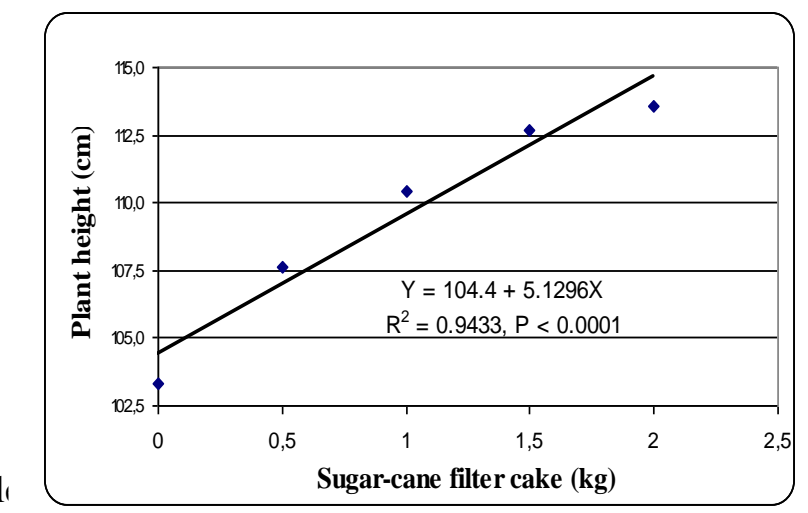

cultıvatıng conaltions, varıety, and age iniluence. Cordova (1965), cited by Santiago (1978), suggested that in coconut tree plantation in the Bicol region, which is highly productive, presented only $0.08,0.16$ and $0.15 \%$ of $\mathrm{P}, \mathrm{Ca}^{2+}$ and $\mathrm{Mg}^{2+}$ contents in leaf, respectively. As so,
Figure 6. Number of live leaves on coconut seedling in function of Mineral fertilizer

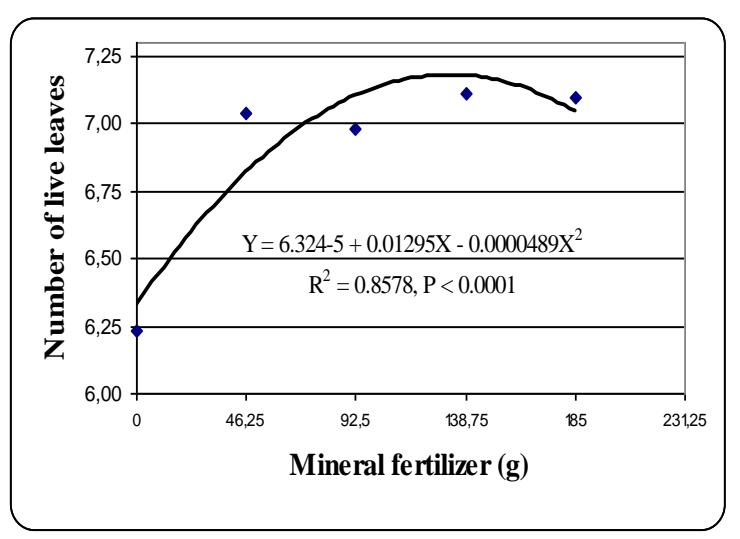

Figure 8. Coconut seedling height $(\mathrm{cm})$ in function of mineral fertilizer

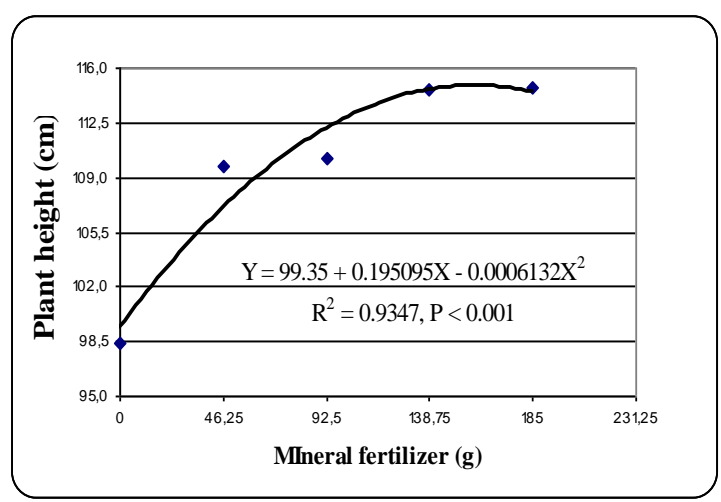

study, even though the biggest doses treatment of the two factors did not reach the critical levels.

The contents of $\mathrm{N}, \mathrm{P}, \mathrm{K}^{+}, \mathrm{Ca}^{2+}$ and $\mathrm{Mg}^{2+}$ in the leaves which remained under critical 
levels, except $\mathrm{P}$, could be due to some factors, $\mathrm{i}$. e: a) $\mathrm{N}$ content - the dilution effect, when compared the results obtained for the parameters studied and critical levels (Table 2) for absolute control and the others treatments; b) P content high content in the SCFC; c) $\mathrm{K}^{+}$content - was the inverse of $\mathrm{P}$, considering its small content in the SCFC and due to the great quantity required by the coconut seedlings; and d) $\mathrm{Ca}^{2+}$ and $\mathrm{Mg}^{2+}$ contents - possibly due to the low content in the SCFC.

The chemical composition changes and organic matter content of the soil before be used as growth media or substrate (Table 3 ) promoted gains for CG, LA, NL and PH due to the SCFC. The $\mathrm{P}$ element content, for instance, changed from low to high status. It may be associated to the phosphate used in sugar-cane soup treatment. There was reduction of $\mathrm{Al}^{3+}$ content, whereas $\mathrm{Ca}^{2+}$ and $\mathrm{Mg}^{2+}$ had their contents increased, but not proportional to the applied doses. The element increasing contents and $\mathrm{Al}^{3+}$ decreasing may be related to the biological fixation process and to the organic matter chelating effects (Castro and Godoy, 1979). The variation of contents, comparing the soil before to be used and the treatment with no SCFC, could be due to the microbiotic at the rizhosphere.

The increasing in the organic matter (Table 3) might have elevated the cation change capacity (CCC) and the moisture retention, contributing to media growth qualities improve and proportioned a seedlings water differentiated level. According to Raij (1969), the CCC varied from 190 to 400 $\mathrm{cmol}_{\mathrm{c}} \mathrm{dm}^{-3}$ for organic matter and from 2.7 to $20.0 \mathrm{cmol}_{\mathrm{c}} \mathrm{dm}^{-3}$ for mineral fraction.

Prasad (1976) recommended mineral phosphorus suppressing when big quantities of
SCFC were used. This position was ratified by Sorace et al. (1981), who stated that phosphate fertilizers were not required when SCFC application was over $20 \mathrm{t} \mathrm{ha}^{-1}$ (the smallest SCFC dose here used corresponded to $66 \mathrm{t} \mathrm{ha}^{-}$ $\left.{ }^{1}\right)$. These authors also assumed that $\mathrm{P}$ in SCFC was more effective than $\mathrm{P}$ of triple superphosphate to increasing $\mathrm{P}$ level in the sugar-cane leaf. Similar results are presented in Table 3, although the effectiveness of $\mathrm{P}$ had not been investigated in this experiment. Paul (1974), working with sugar-cane in soil with $85 \%$ of sand, physically similar to the same used in this experiment, observed four months after SCFC application longer root as well as more quantity and ramification.

The non-significance interaction between the two factors here studied was also verified on sugar-cane (Castro and Godoy, 1979) and on cocoa seedlings (Accioly and Ferraz, 1989).

In general, the results from this research were superior to that obtained in the following coconut seedling characters papers: Santiago (1978) for CG and PH; Passos (1983) for CG, LA and NL; Satyabalan (1984) for CG and NL; and Fontes and Leal (1998) for CG and LA. They are in according to the values admitted as a good coconut seedling for planting, by Wuidart (1981) for CG and PH and by Embrapa (1986) for CG, NL and PH.

The collar girth and leaf production are the two mains criteria to indicate the coconut seedling vigour, suggested for seedling selection (Satyabalan, 1984). Nampoothiri et al. (1975), cited by Satyabalan, 1984, affirmed that there is a genetic relation among these characters and yield of adult plants.

Table 2. Leaf diagnosis in eight months old coconut seedlings, in relation to the sugar-cane filter cake (SCFC) and mineral fertilizer (MF)

\begin{tabular}{|cc|cccccc|}
\hline \multicolumn{2}{|c|}{ Treatment } & \multicolumn{5}{c|}{ Element (in \% of dry matter) } \\
\hline $\begin{array}{c}\text { SCFC } \\
\left(\mathrm{kg} \mathrm{bag}^{-1}\right)\end{array}$ & $\begin{array}{c}\mathrm{MF} \\
\left(\mathrm{g} \mathrm{seedling}^{-1}\right)\end{array}$ & $\mathrm{N}$ & $\mathrm{P}$ & $\mathrm{K}^{+}$ & $\mathrm{Ca}^{2+}$ & $\mathrm{Mg}^{2+}$ & $\mathrm{Na}^{+}$ \\
\hline 0.0 & 00.00 & 1.40 & 0.15 & 1.67 & 0.31 & 0.17 & 0.20 \\
0.0 & 46.25 & 1.24 & 0.16 & 2.26 & 0.24 & 0.12 & 0.11 \\
0.0 & 92.50 & 1.39 & 0.16 & 2.16 & 0.29 & 0.13 & 0.12 \\
0.0 & 138.75 & 1.32 & 0.16 & 2.19 & 0.19 & 0.11 & 0.08 \\
0.0 & 185.00 & 1.25 & 0.17 & 2.36 & 0.29 & 0.12 & 0.08
\end{tabular}




\begin{tabular}{|cc|cccccc|}
0.5 & 00.00 & 1.31 & 0.16 & 1.58 & 0.31 & 0.18 & 0.19 \\
0.5 & 46.25 & 1.24 & 0.16 & 2.10 & 0.26 & 0.13 & 0.10 \\
0.5 & 92.50 & 1.25 & 0.18 & 2.38 & 0.30 & 0.14 & 0.09 \\
0.5 & 138.75 & 1.15 & 0.16 & 2.34 & 0.26 & 0.11 & 0.09 \\
0.5 & 185.00 & 1.26 & 0.18 & 2.46 & 0.29 & 0.20 & 0.08 \\
1.0 & 00.00 & 1.35 & 0.18 & 1.42 & 0.35 & 0.20 & 0.18 \\
1.0 & 46.25 & 1.27 & 0.18 & 2.18 & 0.31 & 0.17 & 0.10 \\
1.0 & 92.50 & 1.07 & 0.17 & 2.14 & 0.26 & 0.13 & 0.09 \\
1.0 & 138.75 & 1.27 & 0.16 & 2.19 & 0.29 & 0.12 & 0.09 \\
1.0 & 185.00 & 1.19 & 0.17 & 2.21 & 0.29 & 0.11 & 0.09 \\
1.5 & 00.00 & 1.30 & 0.19 & 1.38 & 0.36 & 0.21 & 0.20 \\
1.5 & 46.25 & 1.18 & 0.18 & 2.20 & 0.31 & 0.14 & 0.11 \\
1.5 & 92.50 & 1.21 & 0.18 & 2.01 & 0.31 & 0.15 & 0.09 \\
1.5 & 138.75 & 1.17 & 0.16 & 2.17 & 0.33 & 0.11 & 0.10 \\
1.5 & 185.00 & 1.20 & 0.16 & 2.26 & 0.31 & 0.11 & 0.08 \\
2.0 & 00.00 & 1.33 & 0.19 & 1.44 & 0.36 & 0.21 & 0.18 \\
2.0 & 46.25 & 1.15 & 0.18 & 2.21 & 0.33 & 0.15 & 0.10 \\
2.0 & 92.50 & 1.21 & 0.17 & 2.12 & 1.32 & 0.14 & 0.10 \\
2.0 & 138.75 & 1.18 & 0.17 & 2.46 & 0.35 & 0.13 & 0.08 \\
2.0 & 185.00 & 1.15 & 0.17 & 2.37 & 0.31 & 0.12 & 0.08 \\
\hline
\end{tabular}

1 - Manciot et al. (1980).

2 - Magat (1975), for the leaf rank 14.

Table 3. Average chemical composition and organic matter of soil, before use it, and as growing media (soil + SCFC), at the absence of MF, eight months later

\begin{tabular}{|c|c|c|c|c|c|c|c|}
\hline & \multicolumn{2}{|c|}{$\mathrm{g} \mathrm{kg}^{-1}$} & \multicolumn{3}{|c|}{$\mathrm{cmol}_{\mathrm{c}} \mathrm{kg}^{-1}$} & \multirow[t]{2}{*}{$\mathrm{pH}$} & \multirow[t]{2}{*}{ O.M (\%) } \\
\hline & $\mathrm{P}$ & $\mathrm{K}^{+}$ & $\mathrm{Al}^{3+}$ & $\mathrm{Ca}^{2+}$ & $\mathrm{Mg}^{2+}$ & & \\
\hline $\begin{array}{c}\text { Soil } \\
\text { SCFC } \\
\left(\mathrm{kg} \mathrm{bag}^{-1}\right)\end{array}$ & 4 & 12 & 0.7 & $-*$ & $-*$ & 4.5 & 1.12 \\
\hline 0.0 & 9 & 27 & 0.2 & 1.9 & 0.6 & 5.2 & 2.04 \\
\hline 0.5 & 36 & 34 & 0.1 & 2.0 & 0.7 & 5.2 & 2.34 \\
\hline 1.0 & 37 & 29 & 0.1 & 2.1 & 0.6 & 5.4 & 2.26 \\
\hline 1.5 & 67 & 29 & 0.1 & 2.5 & 0.5 & 5.2 & 2.47 \\
\hline 2.0 & 93 & 39 & 0.1 & 2.8 & 0.6 & 4.9 & 2.65 \\
\hline
\end{tabular}

As suggested by Alforja et al. (1978), in this research it was planned to use twelve seedlings per plot. However, due to low germination rate in seedbed and young coconut seedling $( \pm 15 \mathrm{~cm}$ high $)$ selection, there were used six seedlings plot only. Nevertheless the reduced number of seedlings do not interfered on the variance analysis. The experiment presented excellent results to all parameters analysed in relation to the variation coefficients (Table 1).
This performance may be attributed to the hard selection at the seedbed stage.

\section{Conclusions}

It is safe to conclude that it is possible to reduce the quantities of the mineral fertilizers from the up dated $232 \mathrm{~g}$ seedling ${ }^{-1}$ recommendation to $46.5 \mathrm{~g}$ seedling $^{-1}$ only, using as additional fertilizer $0.5 \mathrm{~kg}$ of sugar-cane filter cake bag $^{-1}$. 
After an economic analysis by the coconut farmer about the SCFC use, it is safe to recommend as the best combination $1.5 \mathrm{~kg}$ of SCFC and $46.25 \mathrm{~g}$ of MF.

The SCFC alone should not be used for coconut seedling production in polybags.

The nutrient critical levels in the leaves now are no longer valid to this condition and should be reviewed.

The MF economy of almost $80 \%$ might itself to permit to use polybags for coconut seedling production, particularly for seeds of elite coconut hybrids.

At last, more attention should be, also, given to the number of seedling per plot, considering the variety studied, seedbed selection, number of repetitions and total number of treatments, looking towards reduction of the experimental cost and time.

\section{Acknowledgement}

The authors gratefully acknowledge the assistance of Adailson Machado Freire (São José Sugar Mill), Ângela Vieira (IPA), Artur Nilson dos Santos (IPA), Geraldo Majella Bezerra Lopes (IPA), Júlio Pinilla (autonomous), Lafayette Franco Sobral (Embrapa), Leny Nobre Alecrin (IPA), Laureen Michelle Houllou-Kido (IPA), Manoel Barroso (Matary Sugar Mill), Maria de Lourdes Leal (Embrapa) and Zenaldo Rocha (coconut tree farmer).

\section{References}

ACCIOLY, L.J. de O.; FERRAZ, L.G.B. 1989. Uso de torta de filtro e adubos minerais no preparo de mudas de cacau. Pesquisa Agropecuária Pernambucana. 6 (Número Especial): 61-68.

ALFORJA, L.M.; MAGAT, S.S.; PALOMAR, C.R. 1978. Assessment fertilizer experiment. Philipp J Coconut Study. 3 (3): 15-20.

BRASIL. 1969. Levantamento detalhado dos solos da Estação Experimental de Itapirema. Boletim Técnico 12, p.84.
BRUNIN, C.; COOMANS, P.; OUVRIER, M. 1975. Étude de la nutrition minerale de jaunes cocotiers hybrides en pepiniere. Oléagineux. 30 (6): 251-258.

CASTRO, L.J.P.; GODOY, O.P. 1979. Uso da torta de filtro no sulco de plantio de canade-açúcar (Saccharum spp). Brasil Açucareiro. 94 (5): 66-76.

EMBRAPA. 1986. Produção de mudas de coqueiro. Aracaju, Embrapa/CNPCo, 16p. (Embrapa-CNPCo. Circular Técnica, 2).

EMBRAPA. 1993. Recomendações técnicas para o cultivo do coqueiro. Aracaju, Brasil, Embrapa-CPATC, 44p. (Circular Técnica, 1).

EMBRAPA. Centro Nacional de Pesquisa de Solos (Rio de Janeiro, RJ) 2006. Sistema Brasileiro de Classificação de Solos. Rio de Janeiro: Embrapa Solos, 2006. 306p.

EMATERPE. 1980. Recomendações de adubação para o Estado de Pernambuco. $I^{a}$ aproximação. Recife, Brasil, Ematerpe, $81 \mathrm{p}$.

FONTES, H.R; LEAL, M.de L.da S. 1998. Utilização de sistema alternativo na produção de mudas de coqueiros híbridos (Cocos nucifera L.). Revista Brasileira de Fruticultura. 20 (3) : 290-296.

KRISHNA MARAR, M.M.; PAPPACHAN, G. 1964. A note on the estimation of leaf area in coconut seedlings. The Indian Coconut J. 17 (4): 137-141.

MANCIOT, R.; OLLANIER, M.; OCHS, R. 1980. Nutrition minerale et fertilization du cocotier dans le monde. Oléagineux. 35 (11): 2-55.

MATHEW, C.; RAMADASAN, A. 1964. Effect of N, P, \& $\mathrm{K}$ nutrients on the growth of coconut seedlings. The Indian Coconut J. 17 (4): 114-119.

OHLER, J.G. 1999. Modern coconut management: palm cultivation and products. London, UK, FAO/ Universiteit Leiden, 458 p. 
PASSOS, E.E.M. 1983. Crescimento de plantas de coqueiro durante a fase de enviveiramento. Aracaju, Brasil, Embrapa/CNPCo, 5p. (Comunicado Técnico, 8).

PAUL, C.L. 1974. Effect of filter press mud on soil physical conditions in a sandy soil. Tropical Agriculture. 51 (2): 288-292.

PRASAD, M. 1976. Response of sugar to filter press mud and $\mathrm{N}, \mathrm{P}$ and $\mathrm{K}$ fertilizers. I. Effect on sugar cane yield and sucrose content. Agronomy J. 68 (4): 539-543.

RAIJ, V. VAN. 1969. A capacidade de troca de cátions das frações orgânica e mineral em solos. Bragantia. 28 (8): 84-111.

ROGNON, F. 1971. Les pepinieres de cocotiers en sacs de plastique. Oléagineux. 26 (5): 307-310.

SANTIAGO, R.M. 1978. Growth of coconut seedlings as influenced by different fertility levels in three soil types. Philipp J Coconut Study. 3 (4): 15-27.

SATYABALAN, K. 1984. Nursery studies on West Coast Tall coconut to select seedling for early transplanting. J of Plant Crops. 12 (2): 112-118.

SIQUEIRA, M.A. 1988. Subprodutos industriais da cana no desenvolvimento da pecuária. Revista da Indústria. 17 (1): 36-39.

SORACE, M.A. da F.; CASAGRANDE, A.A.; NAKASATO, Z.B. 1981. Complementação de adubação mineral da cana-de-açúcar (Saccharum spp.) com torta de mamona e de filtro Oliver. Brasil Açucareiro. 98 (4): 55-72.

WUIDART, W. 1981. Production de material vegetal cocotier. Pepinier en sacs plastique. Oléagineux. 36 (7): 367-376. 
Cord 2009, 25 (2) 